\title{
Chromosome divergence and NOR polymorphism in Bryconamericus aff. iheringii (Teleostei, Characidae) in the hydrographic systems of the Paranapanema and Ivaí Rivers, Paraná, Brazil
}

\author{
Thiago Gomes Capistano ${ }^{1}$, Ana Luiza de Brito Portela Castro $^{2}$ and Horácio Ferreira Julio-Junior ${ }^{2}$ \\ ${ }^{1}$ Departamento de Biologia Celular e Genética, Universidade Estadual de Maringá, Maringá, PR, Brazil. \\ ${ }^{2}$ Departamento de Biologia Celular e Genética, Universidade Estadual de Maringá, Nupélia, Maringá, \\ PR, Brazil.
}

\begin{abstract}
Cytogenetic studies were carried out in three populations of Bryconamericus aff. iheringii from two hydrographic systems of the Paranapanema and Ivaí Rivers, separated by a watershed, both belonging to the upper Paraná River ba$\sin$. Specimens had a constant diploid number $2 n=52$ chromosomes. However, three karyotype formulae were identified in the three populations: $B$. aff. iheringii from the Maringá stream had 12M+18SM+8ST+14A (FN = 90); specimens from Keller River showed $8 M+28 S M+6 S T+10 A(F N=94)$ and specimens from the Tatupeba stream had $8 \mathrm{M}+20 \mathrm{SM}+8 \mathrm{ST}+16 \mathrm{~A}(\mathrm{FN}=88)$. Nucleolar organizer regions (NORs) were identified by silver nitrate staining and fluorescent in situ hybridization (FISH) with an 18S rDNA probe. Specimens from Tatupeba stream had a simple NOR system located in a terminal position of the short arm of a pair of large submetacentric chromosomes. Ag-NOR and FISH methodologies revealed multiple NORs in specimens of the Maringá stream and Keller River. Differences in chromosome structure and in NOR patterns in the three populations of $B$. aff. iheringii revealed fixed evolutionary chromosome divergence. Aspects related to karyotypic variations and to geographic isolation of these populations are discussed.
\end{abstract}

Key words: Bryconamericus, Characid fish, chromosome divergence, fluorescent in situ hybridization, NOR polymorphism.

Received: August 22, 2006; Accepted: May 11, 2007.

\section{Introduction}

An important characteristic of nucleolar organizer regions (NORs) in fish is its inter- and intra-species polymorphism. NOR characterization can be a cytogenetic marker of for cytotaxonomic studies and can even aid in constructing phylogenetic hypotheses (cytosystematics) for several fish groups (Amemyia and Gold, 1988; Galetti Jr, 1998; Almeida-Toledo, 2000). Some fish groups present a simple NOR system characterized by ribosomal cistrons on only one chromosome pair, whereas others have a multiple NOR system composed of cistrons dispersed over several chromosomes (Galetti Jr., 1998).

Small characids are characterized by extensive heterogeneity with regard to NOR patterns. A simple NOR system was identified in the species Gymnocorymbus ternetzi (Alberdi and Fenocchio, 1997), Tetragonopterus argenteus (Alberdi and Fenocchio, 1997), Moenkhausia intermedia

Send correspondence to Ana Luiza de Brito Portela Castro. Departamento de Biologia Celular e Genética, Universidade Estadual de Maringá, Av. Colombo 5790, 87020-900 Maringá, PR, Brazil. E-mail: albpcastro@nupelia.uem.br.
(Portela et al., 1988; Portela-Castro and Julio Júnior, 2002) and Moenkhausia costae (Portela et al., 1988). In others characids, occurrence of a multiple NOR system is common, as has been observed in the genus Astyanax, chiefly in the Astyanax scabripinnis complex (e.g., Maistro et al., 1998; Mizoguchi and Martins-Santos, 1998; Mantovani et al., 2000; Marco-Ferro et al., 2001; Souza et al., 2001; Kavalco and Moreira-Filho, 2003; Mantovani et al., 2005). Both conditions have been reported in some cases: specimens of Moenkhausia sanctaefilomenae from the Tietê River (SP, Brazil) analyzed by Foresti et al. (1989) had a multiple NOR system, whereas Moenkhausia sanctaefilomenae from the Paraná River (PR, Brazil) analyzed by Portela-Castro and Júlio Jr. (2002) exhibited a simple NOR pattern. Differentiation in the localization of $18 \mathrm{~S}$ and $5 \mathrm{~S}$ ribosomal sites was detected between two Hyphessobrycon anisitsi populations which presented similar karyotype in number and formulae (Centofante et al., 2003).

Bryconamericus is one of the 88 genera listed as "Incertae sedis" group of the Characidae family with 51 valid species (Lima et al., 2003). Actual diversity in the ge- 
nus Bryconamericus is unknown and its systematics is unresolved. The genus comprises small-sized species, not more than $10 \mathrm{~cm}$ in length, that are distributed throughout several continental aquatic ecosystems in South and Central America (Vari and Siebert, 1990).

Chromosome analyses of the genus Bryconamericus are rare and the diploid number of the species studied up to the moment is restricted to $2 \mathrm{n}=52$ (Portela et al., 1988; Wasko et al., 1996; Wasko and Galetti Jr., 1998; PaintnerMarques et al., 2002a, 2003), although great diversity in chromosome structure has been revealed.

In the current study three populations of Bryconamericus aff. iheringii from two hydrographic systems of the Paranapanema and Ivaí River basins, separated by a watershed were studied. Karyotypes were analyzed with emphasis on the identification of NORs by silver nitrate staining $\left(\mathrm{AgNO}_{3}\right)$ and fluorescent in situ hybridization (FISH) with $18 \mathrm{~S}$ rDNA probes.

\section{Material and Methods}

Cytogenetic studies were carried out in three populations of Bryconamericus aff. iheringii from two hydrographic system of the upper Paraná River basin in the state of Paraná, Brazil (Figure 1): the Maringá stream belongs to the Paranapanema River basin; Keller River and the Tatupeba stream belong to the Ivaí River basin. Amongst the 54 specimens analyzed, 21 (8 males and 13 females) were collected from the Tatupeba stream; 16 specimens ( 5 males and 11 females) were collected from Maringá stream and 17 specimens (10 males and 7 females) were collected from Keller River. Mitotic metaphases were obtained from kidney cells by air-drying, as described by Bertollo et al. (1978). NORs were identified by silver nitrate $\left(\mathrm{AgNO}_{3}\right)$ following the Howell and Black (1980) method, and by fluorescent in situ hybridization (FISH) method with $18 \mathrm{~S}$ rDNA probes. Two types of probes were used to detect $18 \mathrm{~S}$ rDNA segments in FISH analysis: (1) genomic DNA of Astyanax scabripinnis amplified by PCR using the primers NS1 (5'-GTAGTCATATGCTTGTCTC-3') and NS8 (5'TCCGCAGGTTCACCTACGGA-3'), recommended by White et al. (1990); (2) amplified and cloned fragments of Oreochromis niloticus (kindly provided by Dr. Cesar Martins of the Universidade Estadual Paulista, Botucatu, SP, Brazil). The probes were labeled with biotin 14-dATP by nick translation (Bio Nick Labeling System- Gibco, BRL). The FISH protocol followed the methods of HeslopHarrison et al. (1991) and Cuadrado and Jouve (1994).

\section{Results}

Bryconamericus aff. iheringii specimens had a constant diploid number of $2 \mathrm{n}=52$ chromosomes, however, three karyotype formulae were identified. No chromosome differences were found between the sexes.

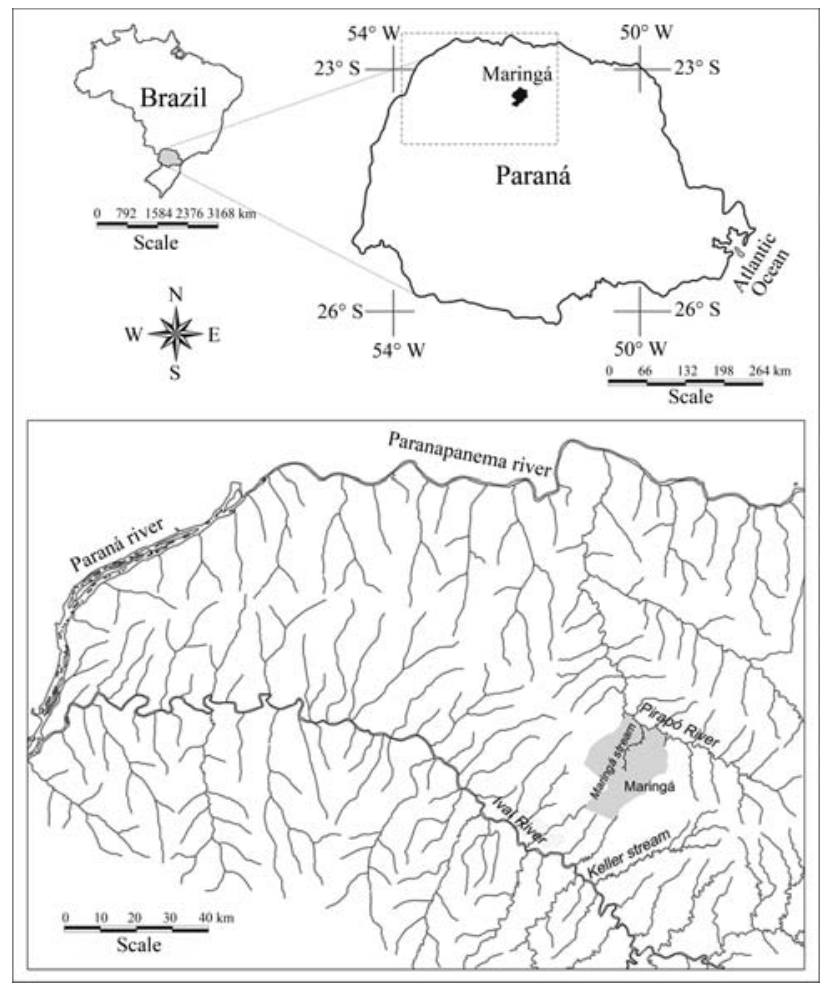

Figure 1 - Hydrographic map showing the draining basins of the Paranapanema and Ivaí Rivers, with collection sites of Bryconamericus aff. iheringii.

\section{Bryconamericus aff. iheringii population of the Maringá stream (Cytotype I)}

This karyotype is composed of $12 \mathrm{M}+18 \mathrm{SM}+8 \mathrm{ST}+$ 14A with fundamental number (FN) of 90, (Figure 2a). Silver nitrate-stained metaphases (Ag-NOR) showed terminal labeling on the short arm of two to four chromosomes, with inter- and intra-individual variation in signal numbers (Figure 3a). By FISH we detected six fluorescent signals of which four corresponded to Ag-NOR chromosomes (Figure $3 \mathrm{~b}$ ). Four fluorescent signals on the telomeres of the short arm of the submetacentric pairs 7 and 10 showed greater intensity, whereas a low intensity fluorescent spot was detected on the telomere of the short arm of submetacentric pair 14. A size heteromorphism occurred on pair 7 .

\section{Population of Bryconamericus aff. iheringii from Keller River (Cytotype II)}

This karyotype is composed of $8 \mathrm{M}+28 \mathrm{SM}+6 \mathrm{ST}+$ $10 \mathrm{~A}$ and $\mathrm{FN}=94$, (Figure 2b). Silver nitrate staining revealed terminal labels in the short arm of two to four chromosomes (Figure 3c), with inter- and intra-individual numerical variations. Ag-NORs sites were eventually detected in the telomere of the long arm of one of the homologs of the large subtelocentric pair. FISH revealed ten ribosomal sites that included Ag-NOR markings (Figure $3 \mathrm{~d})$. Intense fluorescent signals were detected in the short 


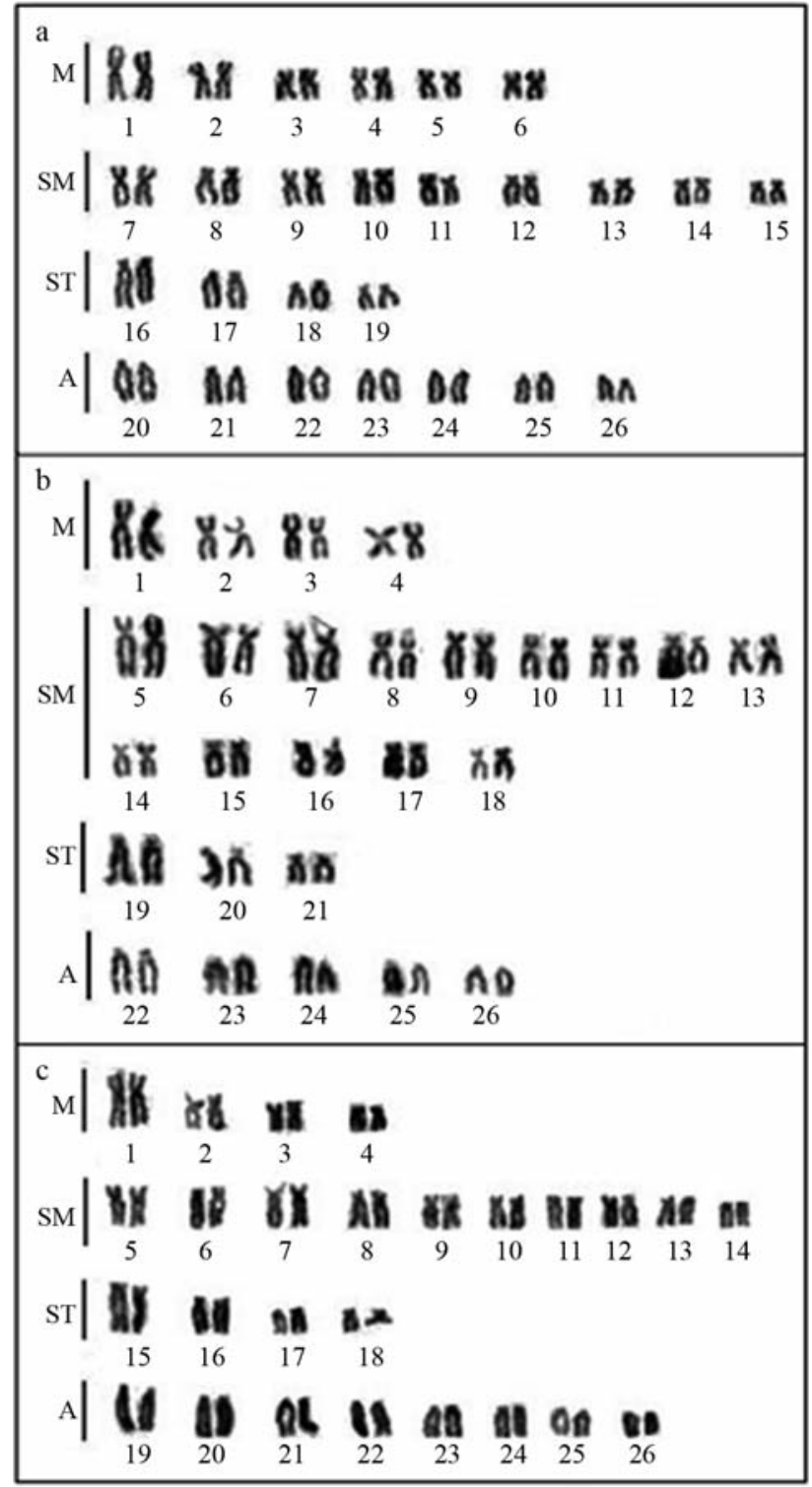

Figure 2 - Giemsa-stained karyotypes of Bryconamericus aff iheringii (a) cytotype I, population from Maringá stream; (b) cytotype II, population from Keller River; (c) cytotype III, population from Tatupeba stream.

arm of submetacentric telomeres (pairs 7 and 8). In addition to the above chromosomes, smaller signs were visible in six more chromosomes which included the Ag-NOR region in a subtelocentric chromosome. Size heteromorphism was detected in chromosome pair 7.

\section{Population of Bryconamericus aff. iheringii from Tatupeba stream (Cytotype III)}

The karyotype structure of these specimens consists of $8 \mathrm{M}+20 \mathrm{SM}+8 \mathrm{ST}+16 \mathrm{~A}, \mathrm{FN}=88$ (Figure 2c). Silver nitrate-stained metaphases showed only one pair of NORbearing submetacentric chromosomes (n. 7) with labeling on the short arm, coinciding with a secondary constriction (Figure 3e). Fluorescent signals confirmed the Ag-NOR

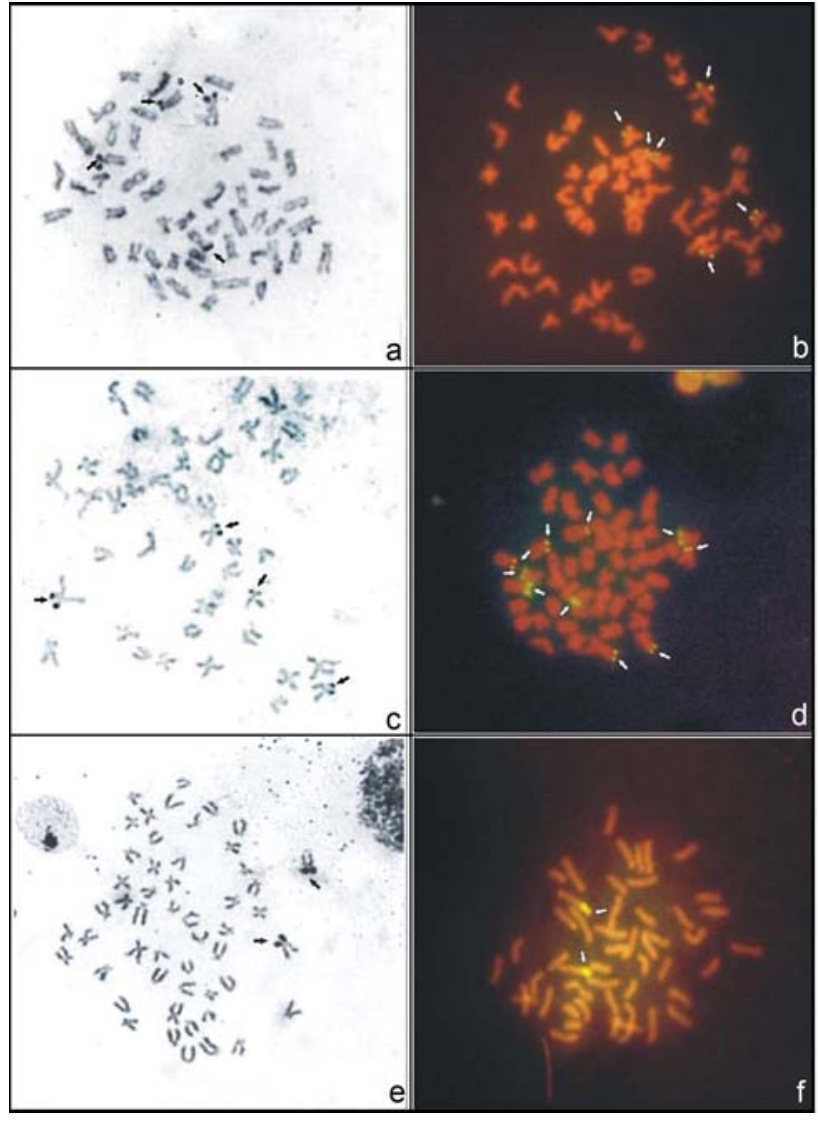

Figure 3 - Metaphases of Bryconamericus aff iheringii specimens showing Ag-NOR - bearing chromosomes (a, c and e) and fluorescent in situ hybridization (FISH) using a $18 \mathrm{~S}$ rDNA probe ( $b, d$ and $\mathrm{f}$ ). The arrows indicate: (a) four Ag-NOR chromosomes and (b) six 18S rDNA sites in the population from Maringá stream; (c) four Ag-NOR chromosomes and (d) ten 18S rDNA sites in the population from Keller River; (e) two Ag-NOR chromosomes and (f) two 18S rDNA sites in the population from Tatubepa stream.

pair by FISH. This chromosome pair also had a NOR-size heteromorphism (Figure 3f).

\section{Discussion}

Although the diploid number of $2 \mathrm{n}=52$ chromosomes is the most frequent one in the genus Bryconamericus, karyotype formulae are variable even at the intra-specific level. Structural chromosome diversity is corroborated by results of the current analysis. PaintnerMarques et al. (2003) reported $2 \mathrm{n}=52$ chromosomes in $B$. aff. iheringii specimens from the Água da Floresta River (Tibagi River basin, Paraná) distributed as $8 \mathrm{M}+22 \mathrm{SM}+$ $10 \mathrm{ST}+12 \mathrm{~A}(\mathrm{FN}=92)$. The three karyotype formulae obtained in the present study and the karyotype reported by Paintner-Marques et al. (2003) suggest the occurrence of fixed extensive evolutionary chromosome diversification in this species. The fundamental number in this genus ranges from 84 to 102 (Portela et al., 1988; Wasko et al., 1996; Wasko and Galetti Jr., 1998; Paintner-Marques et al., 2002a, 2003). Differences in karyotype structure have been 
evidenced mainly as divergence in acrocentric chromosomes number. Variation in the fundamental number (FN) may be the result of chromosome rearrangements of the pericentric inversion type which are considered to be the main mechanism of karyotype evolution in this fish group (Wasko and Galetti Jr., 1998).

Chromosome banding in Bryconamericus species has contributed towards a better understanding of the structural chromosome diversity of the group. Bryconamericus showed extensive variability of NORs (Wasko and Galetti Jr., 1999; Paintner-Marques et al., 2002b), and each species could be characterized by a specific C-banding pattern (Wasko and Galletti Jr., 1998).

A multiple NOR system is the most frequent condition in the genus Bryconamericus. Although the two populations of $B$. aff. iheringii from the Maringá stream and Keller River have multiple ribosomal sites, they differ in the number of NOR-bearing chromosomes, as revealed by the FISH technique. Chromosome rearrangements, such as transposition and/or translocations resulting in dispersion of ribosomal genes, seem to occur in several fish species (Galetti Jr et al., 1995; Castro et al., 1996; Mantovani et al., 2000). These mechanisms may explain NOR variation in each isolated population of $B$. aff. iheringii. Silver nitrate-stained chromosomes (Ag-NOR) in populations of $B$. aff. iheringii with multiple NORs (Maringá stream and Keller River) are less than the number of FISH-identified ribosomal sites. This variation shows that not all ribosomal sites (Ag-NOR) are active. A similar condition has been reported in Bryconamericus aff. exodon, where 2 to $5 \mathrm{Ag}$ NOR sites and eight 18S rDNA sites were detected (Paintner-Marques et al., 2002b). The FISH approach using an $18 \mathrm{~S}$ rDNA probe was extremely important for the distinction between cytotypes I and II with regard to numbers of structural NORs. Additionally, both methodologies revealed a simple NOR pattern in the Tatupeba stream $B$. aff. iheringii population. Although a single nucleolar pair is an uncommon condition in the genus, results are in accordance with the simple NOR system reported in $B$. aff. iheringii of the Tibagi River basin analyzed by Paintner-Marques et al. (2003).

The three populations analyzed have a common NOR phenotype, or rather a pair of large submetacentric chromosomes is always labeled. This submetacentric pair in the three studied populations also showed a more intense fluorescent signal, suggesting that it contains a larger number of rDNA gene copies. These chromosomes may be considered as the main nucleolus organizer and probably contain a cytogenetic marker preserved in this species. Wasko and Galetti Jr. (1999) detected up to 9 Ag-NOR phenotypes in four Bryconamericus species and registered the occurrence of a NOR phenotype (NOR in the short arm of a medium acrocentric chromosome) in three species, indicating that this pair may be an ancient NOR feature among these fishes.
The karyotype divergence and NOR polymorphism detected between the populations of $B$. aff. iheringii suggests that their geographic isolation could favor the fixation of chromosomal rearrangements that probably occurred during karyotype evolution of the genus Bryconamericus. Differential selective pressures in each environment may have been decisive for karyotype differentiation and may have produced the detected chromosome diversification. The above hypothesis is based on the biological characteristics of small characids, which is a group that comprises species with high levels of endemism and fast speciation rates (Böhlke et al., 1978).

According to Silva (2004), Bryconamericus is a polyphyletic genus with many groups of species. Based mainly on the position and shape of maxillary teeth, this author recognized three groups of Bryconamericus species in South America; the groups exodon, microcephalus and iheringii. The latter includes all species found in the southern region of South America. The occurrence of different $B$. aff. iheringii cytotypes requires a detailed taxonomic evaluation of this species, and cytogenetic data can be important tools in their identification.

\section{Acknowledgments}

We would like to thank Dra. Carla S. Pavanelli for taxonomic identification and $\mathrm{CNPq}$ (Conselho Nacional de Desenvolvimento Científico e Tecnológico) for financial support.

\section{References}

Alberdi AJ and Fenocchio AS (1997) Karyotypes of five Tetragonopterinae species (Pisces, Characidae) from Argentina. Cytologia 62:171-176.

Almeida-Toledo LF (2000) Karyotypic evolution in Neotropical freshwater fish. Chrom Today 13:169-182.

Amemiya CT and Gold JR (1988) Chromosomal NORs taxonomic and systematic characters in North American cyprinid fishes. Genetica 76:81-90.

Bertollo LAC, Takahashi CS and Moreira-Filho O (1978) Cytotaxonomic consideration on Hoplias lacerdae (Pisces, Erythrinidae). Rev Bras Genet 1:103-120.

Bölke JE, Weitzman SH and Menezes NA (1978) Estado atual da sistemática dos peixes de água doce da América do Sul. Acta Amazônica 8:657-677.

Castro J, Viñas A, Sánchez L and Martínez P (1996) Characterization of an atypical NOR site polymorphism in brown trout (Salmo trutta) with Ag- and $\mathrm{CMA}_{3}$-staining, and fluorescent in situ hybridization. Cytogenet Cell Genet 75:234-239.

Centofante L, Bertollo LAC, Miyazawa CS and Moreira-Filho O (2003) Chromosomal differentiation among allopatric populations of Hyphessobrycon anisitsi (Pisces, Tetragonopterinae). Cytologia 68:283-288.

Cuadrado A and Jouve N (1994) Mapping and organization of highly-repeated DNA sequences by means of simultaneous and sequential FISH and C-banding in 6x-triticale. Chrom Res 2:331-338. 
Foresti F, Almeida-Toledo LF and Toledo SA (1989) Supernumerary chromosome system, C-banding pattern characterization and multiple nucleolus organizer regions in Moenkhausia sanctaefilomenae (Pisces, Characidae). Genetica 79:107-114.

Galetti Jr PM, Mestriner CA, Monaco PJ and Rasch EM (1995) Post-zygotic modifications and intra -and-inter individual nucleolar organizing regions variations in fish: Report of a case involving Leporinus friderici. Chrom Res 3:285-290.

Galetti Jr PM (1998) Chromosome diversity in neotropical fish. NOR studies. Ital J Zool 65(Suppl):53-56.

Heslop-Harrison JS, Schwarzacher T, Anamthaw-Jónsson K, Leitch AR, Shi M and Leitch IJ (1991) In situ hybridization with automated chromosome denaturation. Technique J Meth Cell Mol Biol 3:109-116.

Howell WM and Black DA (1980) Controlled silver staining of organizer regions with a protective colloidal developer: A 1-step method. Experientia 36:1014-1015.

Kavalco KF and Moreira-Filho O (2003) Cytogenetics analyses in four species of the genus Astyanax (Pisces, Characidae) from Paraíba do Sul River Basin. Caryologia 56:453-461.

Lima FCT, Malabarba LR, Buchup PA, Silva JFP, Vari RP, Harold A, Benine R, Oyakawa OT, Pavanelli CS, Menezes NA, et al. (2003) Characidae- genera Incertae sedis in Characidae. In: Reis RE, Kullander SO and Ferraris Jr CJ (eds) Check List of the freshwater fishes of the South and Central America. EDIPUCRS, Porto Alegre, pp 106-169.

Maistro EL, Oliveira C and Foresti F (1998) Comparative cytogenetic and morphological of Astyanax scabripinnis paranae (Pisces, Characidae, Tetragonopterinae) Genet Mol Biol 21:201-206.

Mantovani M, Abel LDS, Mestriner CA and Moreira-Filho O (2000) Accentuated polymorphism of heterochromatin and nucleolar regions in Astyanax scabripinnis (Pisces, Characidae): Tools for understanding karyotypic evolution. Genetica 109:161-168.

Mantovani M, Abel LDS and Moreira-Filho O (2005) Conserved $5 \mathrm{~S}$ and variable $45 \mathrm{~S}$ rDNA chromosomal localization revealed by FISH in Astyanax scabripinnis (Pisces, Characidae). Genetica 123:211-216.

Marco-Ferro DA, Neo DM, Moreira-Filho O and Bertollo LAC (2001) Nucleolar organizing regions, 18S and 5S rDNA in Astyanax scabripinnis (Pisces, Characidae): Populations distribution and functional diversity. Genetica 110:55-62.

Mizoguchi SMHN and Martins-Santos IC (1998) Activation patterns of the nucleolar organizer region in Astyanax scabripinnis populations (Pisces, Characidae) Cytologia 63:259-265.

Paintner-Marques TR, Giuliano-Caetano L and Dias AL (2002a) Karyotypic diversity in a Bryconamericus aff. exodon population (Characidae, Tetragonopterinae). Cytologia 67:397402.

Paintner-Marques TR, Giuliano-Caetano L and Dias AL (2002b) Multiple NORs in Bryconamericus aff. exodon (Osteichthyes, Characidae, Tetragonopterinae). Hereditas 137:107-112.

Paintner-Marques TR, Giuliano-Caetano L and Dias AL (2003) Cytogenetic characterization of a population of Bryconamericus aff. iheringii (Characidae, Tetragonopterinae). Genet Mol Biol 26:145-149.

Portela ALBS, Galetti Jr PM and Bertollo LAC (1988). Considerations on the chromosome evolution of Tetragonopterinae (Pisces, Characidae). Rev Bras Genet 11:307-316.

Portela-Castro ALB and Júlio-Júnior HF (2002) Karyotype relationships among species of the subfamily Tetragonopterinae (Pisces, Characidae): Cytotaxonomic and evolution aspects. Cytologia 67:329-336.

Silva JFP (2004) Two new species of Bryconamericus Eigenmann (Characiformes, Characidae) from Southern Brazil. Neotrop Ichthyol 2:55-60.

Souza IL, Galían J, De La Rua P, Bertollo LAC and Moreira-Filho O (2001) Non-random distribution and nucleolar rDNA sites on Astyanax scabripinnis chromosomes. Cytologia 66:8591.

Vari RP and Siebert DJ (1990) A new unusually sexually dimorphic species of Bryconamericus (Pisces, Ostariophysi, Characidae) from the Peruvian Amazon. Proc Biol Soc Wash 103:516-524.

Wasko AP, Vênere PC and Galetti Jr PM (1996) Chromosome divergence between two sympatric characid fishes of the genus Bryconamericus. Braz J Genet 19:225-230.

Wasko AP and Galetti Jr PM (1998) Karyotype diversity in the neotropical fish Bryconamericus (Characidae, Tetragonopterinae). Cytobios 94:185-193.

Wasko AP and Galetti Jr PM (1999) Extensive NOR variability in fishes of the genus Bryconamericus (Characidae). Cytologia 64:63-67.

White TJ, Bruns T, Lee S and Taylor J (1990) Amplification and direct sequencing of fungal ribosomal RNA genes for phylogenetics. In: Innis MA, Gelfand DH, Shinsky JJ and White TJ (eds) PCR Protocols: A Guide to Methods and Applications. Academic Press, New York, pp 315-322.

Associate Editor: Fausto Foresti

License information: This is an open-access article distributed under the terms of the Creative Commons Attribution License, which permits unrestricted use, distribution, and reproduction in any medium, provided the original work is properly cited. 